\title{
Accumulation of Potentially Toxic Trace Elements (PTEs) by Native Plant Species Growing in a Typical Gold Mining Area Located in the Northeast of Qinghai-Tibet Plateau
}

\section{Lei Wang}

Lanzhou University

\section{Xiaorong Xie}

Gansu University of Traditional Chinese Medicine

\section{Qifeng Li}

Third institute geological and mineral exploration of Gansu provincial bureau of geology and resource

\section{Zhifeng Yu}

Third institute geological and mineral exploration of Gansu provincial bureau of geology and mineral resource

\section{Guangde Hu}

Lanzhou University

\section{Xixi Wang}

Lanzhou University

Jinrong Liu ( $\square$ liujinr@lzu.edu.cn )

Lanzhou University

\section{Research Article}

Keywords: Potentially toxic trace elements, Mining area, Native plants, Bioaccumulation, Translocation factor, Phytoremediation

Posted Date: June 4th, 2021

DOI: https://doi.org/10.21203/rs.3.rs-437528/v1

License: (c) (i) This work is licensed under a Creative Commons Attribution 4.0 International License. Read Full License

Version of Record: A version of this preprint was published at Environmental Science and Pollution Research on August 31st, 2021. See the published version at https://doi.org/10.1007/s11356-021-16076- 
Page $2 / 24$ 


\section{Abstract}

Though gold mines provide significant economic benefits to local governments, mining causes soil pollution by potentially toxic trace elements (PTEs) in mining areas, especially in the Qinghai-Tibet Plateau. Screening of native plant species from mining areas is now an effective, inexpensive, and ecofriendly method for the remediation of PTEs in situ. In the present study, we conducted experiments to assess the accumulation of $\mathrm{As}, \mathrm{Cd}, \mathrm{Pb}$, and $\mathrm{Zn}$ in 12 native plant species growing on a typical gold mining area in Qinghai-Tibet Plateau. Our results showed that rhizosphere soils have high soil organic matter content, high levels of As, and moderate levels of Cd. G. pylzowianum accumulated relatively higher As in its shoots and exhibited TF higher than 1 for As (4.65), $\mathrm{Cd}$ (1.87), and $\mathrm{Pb}$ (1.36). P. saundersiana had BCF-S higher than 1 for $\mathrm{Cd}$ (4.52) and $\mathrm{Pb}$ (1.70), whereas its TF was higher than 1 for $\mathrm{As}, \mathrm{Cd}, \mathrm{Pb}$, and $\mathrm{Zn}$. These plant species also exhibit strong tolerance to these PTEs. Furthermore, $E$. nutans accumulated low levels of $\mathrm{As}, \mathrm{Cd}, \mathrm{Pb}$, and $\mathrm{Zn}$ in their shoots and exhibited TF values lower than 1 for the four PTEs. Therefore, G. pylzowianum could be used for the in situ phytoextraction of As, and $P$. saundersiana can be used as an effective plant for $\mathrm{Cd}$ and $\mathrm{Pb}$ phytoextraction. E. nutans is better suited for the phytostabilisation of multiple PTEs. Our study is of significant importance for introducing native plant species to remediate PTE-contaminated soils, particularly As and Cd, and has a good potential for developing PTE phytoremediation strategies at mining sites.

\section{Highlights}

As was the prime pollutant in soils surrounding the gold mine.

Phytoremediation of PTEs in 12 native plants was examined at a gold mining site.

P. saundersiana had TF higher than 1 for all PTEs.

P. undersiana and G. pylzowianum are potential phytoextractors of As from soils.

E. nutans has high phytostabilisation potential for all PTEs.

\section{Introduction}

Soils are essential components of terrestrial ecosystems as they play a fundamental role in food safety, ecological stability, and food security (Sun et al., 2019; Keshavarzi and Kumar, 2019). However, with the rapid development of the economy, soil contamination by potentially toxic trace elements (PTEs), which is caused by anthropogenic activities, including mining activities, industrial processes, waste disposal, and land use change (Zeng et al., 2020; Gemeda et al., 2021), has become a severe global problem. Among these activities, mining activities are currently the main source of metal contamination in soils (Zhou and Wang, 2019; Chen et al., 2021a). PTEs in soils pose significant risks to human health via bioaccumulation in plants and animals or bioconcentration in the food chain because of their toxicity, high mobility, and non-biodegradability (Jiang et al., 2018; Fang et al., 2020; Beiyuan et al., 2021). 
Previous studies have found heavy arsenic (As) contamination in gold mining areas, which leads to adverse effects on plant growth and mammalian cells (Aguilar et al., 2020; Tabelin et al., 2020). Additionally, other PTEs, including cadmium (Cd), lead (Pb), chromium $(\mathrm{Cr})$, zinc $(\mathrm{Zn})$ and mercury $(\mathrm{Hg})$, normally co-occur with As in contaminated soils of gold mining areas (Bempah and Ewusi, 2016; Gao, 2018). Therefore, remediating contaminated soils is of great significance in eliminating PTE contamination and reducing the potential ecological risks in the gold mining areas.

Phytoremediation in PTE-contaminated soils has been widely used because of its low cost and ecofriendliness compared with traditional physical or chemical approaches (Ju et al., 2020; Kanwar et al., 2020). Phytoremediation, including phytoextraction and phytostabilisation, has shown satisfactory results, and relies on the natural capacity of plants to remove or stabilise metal pollutants in contaminated sites (Cheraghi-Aliakbari et al., 2020; Egendorf et al., 2020). The uptake, translocation, and accumulation of pollutants in soil-plant systems mainly depend on the plant species (Jiang et al., 2018). Currently, only a few plant species have been identified to hyper-accumulate PTEs in their harvested parts. Therefore, more studies are needed to identify potential PTE hyper-accumulators. Native plant species preferred for phytoremediation as they have strong resistance to an excess of PTEs from the contaminated sites and pose no ecological risk to the local ecosystem (Aihemaiti et al., 2017; Hasnaoui et al., 2020). Additionally, polluted sites with unique climates may not be suitable for the growth of exotic hyper-accumulator plants. Furthermore, soil properties play a key role in controlling metal uptake by plants (Wang et al., 2020). Recently, Yu et al. (2021) indicated that the phytoremediation efficiency was correlated with soil pH and nutrients as they directly or indirectly changed the bioavailability of PTEs in soil-plant systems.

Hezuo City, located in the northeast of the Qinghai-Tibet Plateau, is rich in mineral resources such as copper (Cu), iron (Fe), and As, and is especially rich in gold. Zaozigou, which is located in the western zone of Hezuo City, is the largest gold mine in Gansu Province and has been explored for more than 26 years (Sui et al., 2018). Gold mines provide significant economic benefits to the local government. Nevertheless, this region is also severely affected by the presence of excessive mining activities and inadequate treatment of wastewater, leading to soil contamination by PTEs (Hu et al., 2020). In this context, the main aims of this research were to (1) assess the total concentrations of PTEs (As, Cd, Zn, and $\mathrm{Pb}$ ) and the soil chemical properties in rhizospheric soil; (2) explore the uptake, translocation, and accumulation of PTEs in 12 native dominant plant species; and (3) screen and assess the phytoremediation potential of native plant species found in the mining area.

\section{Materials And Methods}

\subsection{Site description}

The sampling sites (Zaozigou gold mine) are located northeast of the Qinghai-Tibet Plateau, Hezuo city, Gansu Province, China ( $34^{\circ} 56^{\prime} \mathrm{N}-34^{\circ} 59^{\prime} \mathrm{N}$ and $102^{\circ} 47^{\prime} \mathrm{E}-102^{\circ} 51^{\prime} \mathrm{E}$ ), which is classified as having a cold and humid alpine climate, with a mean annual rainfall of $545 \mathrm{~mm}$. The altitude of the study area 
ranges from 2960 to $3520 \mathrm{~m}$. The mean temperature is $11.7^{\circ} \mathrm{C}$ in summer and $-10.7^{\circ} \mathrm{C}$ in winter, and the area has an average of 270 frost days per year. Various plant species are found in the gold mining area, and the area is polluted with multiple metals and As (Hu et al., 2020).

\subsection{Rhizosphere soil and plant sample collection and analysis}

This study was conducted in September 2020 in the gold mining area. Soil samples were collected from the rhizosphere soils $(0-20 \mathrm{~cm})$ of plants via a soil sampler and shaking the soil, after which the plant samples were uprooted. After removing stones and other debris, the soil samples were air-dried and ground to a fine powder. Three replicates were prepared and used for the analyses, and a total of 36 soil samples were included. Soil pH and conductivity (EC) were determined using a water/soil ratio of 5:1 in an aqueous suspension. Soil organic matter (SOM) was analysed by the oxidation method with $\mathrm{K}_{2} \mathrm{Cr}_{2} \mathrm{O}_{7^{-}}$ $\mathrm{H}_{2} \mathrm{SO}_{4}$ followed by titration with $\mathrm{FeSO}_{4}$ (Yuan et al., 2011). Soil total potassium (TN) was measured based on the method described by Estefan et al. (2013) using a Foss Kjeltec analyser. Total phosphorus (TP) was measured using the acid digestion method (Hu et al., 2018). To determine the PTE concentrations in soil, air-dried soil samples $(0.5 \mathrm{~g})$ were digested in $\mathrm{HNO}_{3}: \mathrm{HClO}_{4}(5: 1, \mathrm{v} / \mathrm{v})$ at $180{ }^{\circ} \mathrm{C}$ for 6 h. The PTE concentrations in the soil samples were measured using an inductively coupled plasma mass spectrometer (Agilent, Santa Clara, CA, USA).

Plant samples were collected in September 2020 from the same sites as the soil samples. Twelve plant species in this area were collected: Poa pratensis L., Elymus nutans Griseb., Potentilla saundersiana Royle, Geranium pylzowianum Maxim., Carpesium lipskyi Winkl., Ligularia sagitta (Maxim.) Mattf., Potentilla fruticosa L., Artemisia frigida Willd., Rumex nepalensis Spreng., Taraxacum mongolicum Hand.-Mazz., Gentianopsis paludosa (Hook. f.) Ma, and Swertia tetraptera Maxim (Fig. 1). These native plant species were chosen based on high abundance and vitality. At each sampling site, three to five individual plants were randomly collected. All plants had healthy root systems and no leaf chlorosis. Triplicates of each plant species were also collected. Plant species were identified on the basis of the Plant Photo Bank of China. The entire plants were carefully washed thrice with tap water, carefully rinsed with deionised water, separated into shoots and roots, airdried and oven-dried at $72{ }^{\circ} \mathrm{C}$ for $48 \mathrm{~h}$, and ground into a powder. The samples were digested with $15 \mathrm{ml}$ $\mathrm{HNO}_{3}$ and $5 \mathrm{ml} \mathrm{HClO}_{4}$ and then filtered. After filtration, the total PTE (Cd, Pb, Zn, and As) concentrations of the digested solutions were determined using ICP-MS.

\subsection{Statistical analysis}

Bioconcentration factor (BCF) is defined as the ratio of PTE concentrations in plant tissue, and represents the absorbing ability of PTEs from the soils by plants (Chen et al., 2020) (Eq. 1). The ability of translation of PTEs in roots of plants in relation to shoots is evaluated using the Translocation factor (TF) (Chen et al., 2020) (Eq. 2)

$\mathrm{BCF}=\mathrm{C}_{\text {shoot }} / \mathrm{C}_{\text {soil }} \quad$ (Eq. 1) 
$\mathrm{TF}=\mathrm{C}_{\text {shoot }} / \mathrm{C}_{\text {root }}$

where $\mathrm{C}_{\text {soil, }} \mathrm{C}_{\text {shoot, }}$ and $\mathrm{C}_{\text {root }}$ are the PTE concentrations of the soil, aerial parts of plants, and root parts of plants, respectively.

Data were processed using Excel 2013, and the statistical analysis was performed with SPSS 23 for windows. Figures were drawn using the Origin 2018b software. Mean values based on triplicate measurements were calculated. The means were compared using the least significant difference (LSD) test to determine marked differences between different treatments $(p<0.05)$.

\section{Results}

\subsection{Rhizosphere soil characterization}

The chemical properties of the rhizosphere soil from the study area are given in Table 1. The pH of rhizosphere soil ranged from 7.29 to 8.08 , suggesting that all sampling sites were alkaline. The EC varied from 73.43 to $118.07 \mathrm{mS} \mathrm{m}^{-1}$, with the highest value observed at the rhizosphere soil of T. mongolicum. The SOM ranged from 37.28 to $93.56 \mathrm{~g} \mathrm{~kg}^{-1}$, with a marked difference $(p>0.05)$ between the rhizosphere soils of $P$. fruticosa and G. paludosa. The rhizosphere soils of $P$. pratensis had relatively high amounts of TN and TP. Soil TN varied among different rhizosphere soils, and the rhizosphere soils of G. pylzowianum had the lowest value.

\subsection{PTEs concentrations in rhizosphere soils}

The contents of $\mathrm{As}, \mathrm{Zn}, \mathrm{Cd}$, and $\mathrm{Pb}$ in the rhizosphere soils of the identified plant species are shown in Fig. 2. In this study, most of the As concentrations in the soil were exceeding the threshold limits of China (GB 15618-2018) (25 mg kg-1), ranging from 22.61 to $144.22 \mathrm{mg} \mathrm{kg}^{-1}$. For the concentrations of Cd, most of the rhizosphere soils were under the threshold $\left(0.5 \mathrm{mg} \mathrm{kg}^{-1}\right)$, but the average values in all rhizosphere soils exceeded the background values $\left(0.1 \mathrm{mg} \mathrm{kg}^{-1}\right)$. The concentration of $\mathrm{Zn}$ and $\mathrm{Pb}$ in the rhizosphere soils ranged from 79.94 to $88.78 \mathrm{mg} \mathrm{kg}^{-1}$ and 27.23 to $40.53 \mathrm{mg} \mathrm{kg}^{-1}$, respectively, and all of them were high than their background values (74.2 $\mathrm{mg} \mathrm{kg}^{-1}$ for $\mathrm{Zn}$ and $26.0 \mathrm{mg} \mathrm{kg}^{-1}$ for $\mathrm{Pb}$ ).

\subsection{PTEs concentrations in native plants}

\subsubsection{Arsenic}

PTEs can be absorbed by plants from soil. In this study, the PTE concentrations in the plant tissues of the identified plants were highly variable (Fig. 2). In this study, As concentrations in shoots ranged from 2.56 to $31.08 \mathrm{mg} \mathrm{kg}^{-1}$, and those in roots ranged from 2.17 to $56.74 \mathrm{mg} \mathrm{kg}^{-1}$. The highest As concentrations were recorded in the shoots and roots of $S$. tetraptera, which were only equal to approximately $21.55 \%$ and $39.34 \%$ of soil As concentrations, respectively. The shoots of $R$. nepalensis and G. pylzowianum and 
the roots of $P$. pratensis and $E$. nutans also accumulated marked amounts of As. However, L. sagitta accumulated low levels of As in shoots $\left(2.57 \mathrm{mg} \mathrm{kg}^{-1}\right)$ and roots $\left(6.36 \mathrm{mg} \mathrm{kg}^{-1}\right)$.

\subsubsection{Cadmium}

In this study, the total Cd concentrations in the shoots and roots were also markedly different between the plant species (Fig. 3). The Cd concentrations ranged from 0.05 to $2.07 \mathrm{mg} \mathrm{kg}^{-1}$ for shoots and from 0.10 to $1.37 \mathrm{mg} \mathrm{kg}^{-1}$ for roots (Fig. 3). The highest Cd contents were observed in the shoots and roots of $S$. tetraptera. The Cd contents in the shoots of $P$. saundersiana, C. lipskyi, L. sagitta, A. frigida, and $S$. tetraptera were markedly higher than those in their rhizosphere soils.

\subsubsection{Lead}

The $\mathrm{Pb}$ content in the shoots of 12 investigated plants, except $P$. saundersiana, $P$. fruticosa, A. frigida, and T. mongolicum, were higher than those in their rhizosphere soils (Fig. 4). The highest shoot $\mathrm{Pb}$ concentrations were found in $P$. saundersiana, which was approximately 1.5 times higher than the soil $\mathrm{Pb}$ levels. The roots of $P$. saundersiana also showed a strong capacity to absorb $\mathrm{Pb}$ from the soil. Additionally, the $\mathrm{Pb}$ content in the roots of $G$. paludosa was up to $29.46 \mathrm{mg} \mathrm{kg}^{-1}$, which was markedly higher than those recorded in other plant species. The lowest concentration of $\mathrm{Pb}$ was found in $E$. nutans (3.64 $\left.\mathrm{mg} \mathrm{kg}^{-1}\right)$ for shoots and L. sagitta $\left(13.14 \mathrm{mg} \mathrm{kg}^{-1}\right)$ for roots.

\subsubsection{Zinc}

Total $\mathrm{Zn}$ concentrations in shoots and roots were markedly different between the plant species. The $\mathrm{Zn}$ concentrations in the shoots and roots ranged from 11.40 to $44.62 \mathrm{mg} \mathrm{kg}^{-1}$ and 21.05 to $50.44 \mathrm{mg} \mathrm{kg}^{-1}$, respectively. In the current study, the maximum $\mathrm{Zn}$ accumulation in the shoots was recorded in $T$. mongolicum. Additionally, root Zn contents in P. pratensis and E. nutans were 50.44 and $48.71 \mathrm{mg} \mathrm{kg}^{-1}$, respectively, which were markedly higher compared to those of the other 10 plant species (Fig. 5). The lowest $\mathrm{Zn}$ content $\left(11.40 \mathrm{mg} \mathrm{kg}^{-1}\right)$ in shoots was recorded in $E$. nutans, suggesting that $E$. nutans may be a potential low accumulator of $\mathrm{Zn}$. Moreover, in most of native plant species, the $\mathrm{Zn}$ content in the shoots was markedly lower than that recorded in the roots, indicating that $\mathrm{Zn}$ had a low translocation rate from roots to shoots compared to $\mathrm{As}, \mathrm{Cd}$, and $\mathrm{Pb}$.

\subsection{PTEs uptake and translocation by 12 investigated plants}

The efficiency of PTE uptake by native plants and its translocation can be evaluated using BCF-S and TF, respectively. A BCF-S higher than 1 indicates that the plant is efficient at absorbing and accumulating PTEs from the soils, while low BCF-S values indicate that the plant excludes. Plants with both BCF-S and TF values higher than 1 may be potential hyper-accumulators. However, plants with both BCF-S and TF values much less than 1 can stabilise PTEs in the soils. The BCF-S and TF values for the native plant species analysed in this study are shown in Fig. 6 and 7, respectively. In this study, all plant species had a BCF-S value lower than 1 for As. Among these, G. pylzowianum and P. fruticosa showed relatively high 
BCF-S of 0.79 and 0.58 for As, respectively. Among 12 investigated plant species, E. nutans was found growing in heavy As-contaminated soils, and showed BCF-S of 0.10, 0.32, 0.13, and 0.11 for As, Cd, Zn and $\mathrm{Pb}$, respectively, suggesting that $E$. nutans has great potential to stabilise $\mathrm{As}, \mathrm{Cd}, \mathrm{Zn}$, and $\mathrm{Pb}$ in the contaminated soils. P. saundersiana showed the highest BCF-S for $\mathrm{Cr}$ and $\mathrm{Cu}$, which were 4.52 and 1.70, respectively. In addition, no plant species showed BCF-S $>1$ for $Z n$, suggesting that $Z n$ is not easily absorbed by plant shoots.

Most of the native plants showed high translocation capacities for As and Cd (Fig. 7). A relatively high TF for As was found in G. Pylzowianum (4.65) and P. fruticosa (3.97). In addition, they had TF values higher than 1 for $\mathrm{Cd}$ and $\mathrm{Pb}$. However, P. pratensis and E. nutans showed TF values lower than 1 for $\mathrm{As}, \mathrm{Cd}, \mathrm{Zn}$, and $\mathrm{Pb}$. The maximum TF (6.65) of $\mathrm{Cd}$ was recorded in $P$. saundersiana; which also had a TF higher than 1 for As (2.12), $\mathrm{Pb}$ (2.54), and Zn (1.05).

In the current study, no single plant exhibited both BCF-S and TF values higher than 1 for As concurrently, but $P$. saundersiana accumulated and translocated high levels of $\mathrm{As}, \mathrm{Cd}$, and $\mathrm{Pb}$. Additionally, $P$. saundersiana was found growing in heavy As-polluted and moderately Cd-contaminated soils, demonstrating that $P$. saundersiana has the potential for phytoextraction of As and Cd from soils. For As, $\mathrm{Cd}, \mathrm{Zn}$, and $\mathrm{Pb}$ for all the investigated plants, BCF-S and TF values lower than 0.5 were only observed for E. nutans. Thus, E. nutans can be used to phytostabilise these PTEs in soils.

\section{Discussion}

PTE bioavailability drives its biogeochemical behaviour in soil-plant systems, which plays an important role in PTE uptake by plants (Nejad et al., 2021). The most important factor affecting PTE bioavailability was soil chemical properties, such as soil pH, SOM, and nutrient content (Ali et al., 2020). In this study, all sampling sites had alkaline $\mathrm{pH}$, which may be attributed to the impact of mining activities. These results confirm the phenomenon found by Barakan et al. (2019) related to soils of a similar gold mine, which indicated that the discharge of the alkaline mine wastewater may cause the alkalinity of the soil and the release of As and other elements into the soil environment. Electrical conductivity (EC) can enhance PTE precipitation and complexation, decrease the mobility and bioavailability of PTEs, and consequently reduce PTE accumulation in plant tissues (Aihemaiti et al., 2017). However, our study found that soil EC had no marked effect on PTE accumulation in plant shoots (Table S1), probably due to the low soil EC in the investigated soils. SOM, originating from the decomposition of plant, animal, and microbial material, has a high affinity for PTEs to increase its adsorption ability (Chen et al., 2021b). Generally, higher SOM content determines more PTE sorption sites, and thus reduces the bioavailability in soils (Hu et al., 2019). In this study, all investigated soils exhibited very high concentrations of SOM, as per the national standard, and had no significant effect on PTE accumulation in the shoots (Table S1). Furthermore, soil nutrients are crucial factors governing plant growth and influence PTE accumulation in plant tissues, such as TN and TP (Miranda et al., 2021). In this study, soil nutrients were within a high range, including high TN (more than $2 \mathrm{~g} \mathrm{~kg}^{-1}$ ) and extremely low TP (lower than $0.5 \mathrm{~g} \mathrm{~kg}^{-1}$ ) (Xu et al., 2018). Meanwhile, 
total N, P, and PTE contents in the soil were not markedly correlated with each other, indicating that N, P, and PTEs in these soils originated from different sources (Table S1).

Compared to the Chinese national standards, $\mathrm{As}, \mathrm{Cd}, \mathrm{Zn}$, and $\mathrm{Pb}$ levels in the soils exceeded the background values of $11.5,0.1,11.2$, and $26.0 \mathrm{mg} \mathrm{kg}^{-1}$, respectively, and As and Cd concentrations surpassed their permissible limits. However, the native plants did not exhibit high levels of As in their tissues. The result for the reason could be due to the high soil SOM, which decreased As mobility and bioavailability and thus affected As uptake by plant roots (Hu et al., 2019). The differences among plant species and strong phytotoxicity of As could also have led to the low As accumulation.

In the present study, the 12 native plant species were capable of growing in soils that varied widely in this study area contaminated with As and $\mathrm{Cd}$, with concentrations exceeding the Chinese national standards. This indicates that these plants have a strong tolerance for As and Cd. In recent years, few studies have explored the behavior of As uptake by native plant species. In our study, As was mainly retained in the roots of all plant species, which is similar to the findings of Wei and Chen. (2006), Sharifi et al. (2012), and Liu et al. (2014). Among these plant species, G. pylzowianum, R. nepalensis, and S. tetraptera had relatively higher As concentrations in their shoots, even though these plants were found in the heavy Ascontaminated soil. The difference in As accumulation and distribution among the plant species are the result of complex interactions between chemical and biological factors (Aihemaiti et al., 2017). Meanwhile, As accumulation was found to be closely related to the soil As level. Although S. tetraptera accumulated $31.08 \mathrm{mg} \mathrm{kg}^{-1}$ As in its shoots, the sampling sites had the highest soil As concentration $\left(144.22 \mathrm{mg} \mathrm{kg}^{-1}\right)$, and thus it may be not a suitable As phytoextractor candidate. In contrast, $G$. pylzowianum and $P$. fruticosa showed a strong capacity to absorb and translocate As, suggesting that accumulation and distribution of As is very plant-specific. The phenomenon may be attributed to the difference in aboveground biomass of these plant species, which can dilute the level of As in shoots and enhance the tolerance of plants to As toxicity.

Different results were found for $\mathrm{Cd}, \mathrm{Zn}$, and $\mathrm{Pb}$ concentrations in the plant tissue. Cd is not essential for plants and is considered toxic at low levels for most plant species (Wang et al., 2021). In the current study, Cd exhibited an inverse distribution pattern to that of As in the investigated plants. Six plant species showed high levels of $\mathrm{Cd}$ accumulation in their shoots and transferred marked levels of $\mathrm{Cd}$ from their roots to shoots. S. tetraptera accumulated the highest Cd levels in its shoots and roots, and both BCF-S and TF were higher than 1, indicating that the plant may be useful as a potential Cd hyperaccumulator to remove $\mathrm{Cd}$ from contaminated soils. Moreover, $\mathrm{S}$. tetraptera grew at the most $\mathrm{Cd}-$ contaminated soils, thus leading to increased Cd levels in its roots and shoots. A possible reason is that $\mathrm{Cd}$ is distributed to non-photosynthetically active organs in plant tissues to reduce $\mathrm{Cd}$ toxicity by biomass diffusion (Choppala et al., 2014; Haider et al., 2021). Lotfolahi et al. (2011) also reported that shoots of Helianthus annuus accumulate greater Cd levels than those of roots. However, several plant species accumulate higher $\mathrm{Cd}$ levels in their roots than in their shoots, indicating that $\mathrm{Cd}$ accumulation patterns in plant species are highly variable (Shackira and Puthur, 2017). 
$\mathrm{Pb}$ is a highly toxic element that does not play a beneficial role in the physiological and biochemical processes of plants. Among the investigated plants, $P$. saundersiana exhibited the highest $\mathrm{Pb}$ levels (67.98 $\mathrm{mg} \mathrm{kg}^{-1}$ ) in shoots, and $P$. saundersiana had the highest BCF and TF of 1.70 and 2.54, respectively, which indicated high accumulation and translocation efficiency. Our findings are in accordance with those of Egendorf et al. (2020), who reported that Vetiveria zizanoides had higher Pb levels in its shoots than its roots and exhibited a strong capacity to accumulate $\mathrm{Pb}$ in its shoots. Unlike the other three PTEs, $\mathrm{Zn}$ is an essential element for plants when present in lesser amounts, while in excessive amounts it exerts detrimental effects on plant growth and development (Rizwan et al., 2019). The highest shoot $\mathrm{Zn}$ levels were recorded in $P$. saundersiana and $A$. frigida, which were markedly lower than the $\mathrm{Zn}$ accumulation in plants in other studies, such as Lolium perenne L. (Zhang et al., 2019) and Salix spp. (Yang et al., 2020). This possible reason is the lower soil $\mathrm{Zn}$ levels in the study area compared with those in other Zn-contaminated soils (Zhang et al., 2019; Yang et al., 2020). In addition, Zn is difficult to accumulate in plants in the aboveground parts compared to the other three PTEs. Lam et al. (2017) also reported that $\mathrm{Zn}$ was actively transported to plant shoot tissues as $\mathrm{Zn}$ plays an important role in many plant functions, which is not consistent with our result that most plant species have higher $\mathrm{Zn}$ levels in their roots. A possible reason is that $\mathrm{Zn}$ uptake and translocation of plant species are highly variable and dependent on the soil matrix and climatic conditions (Pinto et al., 2014; Aihemaiti et al., 2017).

Among the 12 native plant species, G. pylzowianum exhibited TF values higher than 1 for As (4.65), Cd (1.87), and $\mathrm{Pb}(1,36)$, while G. pylzowianum had the highest BCF-S values of 0.79 for As. The results clearly suggest that G. pylzowianum has potential use as an As hyper-accumulator, which is inexpensive, simple to operate, and more eco-friendly for cleaning As-contaminated soils in gold mining areas. $P$. saundersiana had TF values of $2.12,6.65,2.54$, and 1.05 for $\mathrm{As}, \mathrm{Cd}, \mathrm{Pb}$, and $\mathrm{Zn}$, respectively. Additionally, it had BCF-S values of 4.52 and 1.70 for $\mathrm{Cd}$ and $\mathrm{Pb}$, respectively. The reason for its strong accumulation and translocation capacities is ascribed to their large and deep root systems. Thus, $P$. saundersiana can be considered a potential hyper-accumulator for the remediation of soils contaminated with $\mathrm{Cd}$ and $\mathrm{Pb}$. $E$. nutans accumulated relatively low amounts of $\mathrm{As}, \mathrm{Cd}, \mathrm{Pb}$, and $\mathrm{Zn}$ in its shoots, and had a TF lower than 0.4 for all PTEs, indicating that the plant species had a strong ability to mobilise these PTEs into its roots. Thus, E. nutans could be considered as a potential candidate for the phytostabilisation of multiple PTEs (As, $\mathrm{Cd}, \mathrm{Pb}$, and $\mathrm{Zn}$ ) in the gold mining area.

\section{Conclusion}

In this study, we explored the PTE concentrations in 12 native plant species and their rhizosphere soils surrounding a typical gold mining area in the northeast of the Qinghai-Tibet Plateau. The 12 native plant species appeared to be well adapted to the gold mining area. Meanwhile, the concentrations of PTEs in plants and their rhizosphere soils varied markedly. Of the plant species evaluated, G. pylzowianum accumulated high levels of As in its shoots and had a TF higher than 1 for As, Cd, and Pb. Thus, it could be considered a potential hyper-accumulator for As. P. saundersiana was suitable for phytoextraction of 
both As and Cd because of the high amounts of As and Cd in their shoots and both BCF-S and TF values higher than 1. For the first time, E. nutans was proposed as a candidate stabiliser for multiple PTEs. Thus, it was suitable for phytostabilisation in multiple PTE-contaminated soils. Based on the basis of these findings, our study provides insight in development of plant species that are suitable in situ for phytoremediation, particularly those located in the Qinghai-Tibet Plateau.

\section{Declarations}

\section{Authors Contributions}

Lei Wang: conceptualization, investigation, writing the original draft and analysis

Xiaorong Xie: investigation and made suggestions of the manuscript

Qifeng Li\& Zhifeng Yu: investigation and formal analysis

Guangde Hu\& Xixi Wang: investigation and data curation

Jinrong Liu: editing and corresponding author

\section{Funding}

This work was financially supported by the Key R \& D Program of Gansu Province, China(17YF1NA065); the Gansu Special Project for Guiding Innovation and Development of Science and Technology, China (2018ZX-09).

\section{Competing Interests}

The authors declare that they have no competing interests.

\section{Availability of data and materials}

Most data generated or analyzed during this study are included in this manuscript. Further data used during the current study are available from the corresponding author on reasonable request.

\section{Ethical Approval[}

Not applicable.

\section{Consent to Participate:}

Not applicable.

\section{Consent to Publish:}

Not applicable. 


\section{References}

Aguilar, N.C., Faria, M.C., Pedron, T., Batista, B.L., Mesquita, J.P., Bomfeti, C.A., Rodrigues, J.L., 2020. Isolation and characterization of bacteria from a brazilian gold mining area with a capacity of arsenic bioaccumulation. Chemosphere 240, 124871.

Aihemaiti, A., Jiang, J., Li, D.A., Li, T., Zhang, W., Ding, X., 2017. Toxic metal tolerance in native plant species grown in a vanadium mining area. Environ. Sci. Pollut. Res. 24, 34, 26839-26850.

Ali, A., Shaheen, S. M., Guo, D., Li, Y., Xiao, R., Wahid, F., Azeem, M., Sohail, K., Zhang, T., Rinklebe, J., Li, R., Zhang, Z., 2020. Apricot shell-and apple tree-derived biochar affect the fractionation and bioavailability of $\mathrm{Zn}$ and $\mathrm{Cd}$ as well as the microbial activity in smelter contaminated soil. Environ. Pollut. 264, 114773.

Barakan, S., Aghazadeh, V., 2019. Structural modification of nano bentonite by aluminum, iron pillarization and 3D growth of silica mesoporous framework for arsenic removal from gold mine wastewater. J. Hazard. Mater. 378, 120779.

Beiyuan, J., Fang, L., Chen, H., Li, M., Liu, D., Wang, Y., 2021. Nitrogen of EDDS enhanced removal of potentially toxic elements and attenuated their oxidative stress in a phytoextraction process. Environ. Pollut. 268, 115719.

Bempah, C.K., Ewusi, A., 2016. Heavy metals contamination and human health risk assessment around Obuasi gold mine in Ghana. Environ. Monit. Assess. 5, 261.

Chen, L., Yang, J. Y., Wang, D., 2020. Phytoremediation of uranium and cadmium contaminated soils by sunflower (Helianthus annuus L.) enhanced with biodegradable chelating agents. J. Cleaner Prod. 263, 121491.

Chen, L., Hu, W. F., Long, C., Wang, D., 2021a. Exogenous plant growth regulator alleviate the adverse effects of $U$ and $C d$ stress in sunflower (Helianthus annuus $L$.) and improve the efficacy of $U$ and $\mathrm{Cd}$ remediation. Chemosphere 262, 127809.

Chen, L., Liu, J., Zhang, W., Zhou, J., Luo, D., Li, Z., 2021b. Uranium (U) source, speciation, uptake, toxicity and bioremediation strategies in soil-plant system: A review. J. Hazard. Mater.413, 125319.

Cheraghi-Aliakbari, S., Beheshti-Alagha, A., Ranjbar, F., Nosratti, I., 2020. Comparison of Myagrum perfoliatum and Sophora alopecuroides in phytoremediation of $\mathrm{Cd}$-and $\mathrm{Pb}$-contaminated soils: $\mathrm{A}$ chemical and biological investigation. Chemosphere 259, 127450.

Choppala, G., Saifullah, Bolan, N., Bibi, S., Iqbal, M., Rengel, Z., Kunhikrishnan, A., Ashwath, N., Ok, Y.S., 2014. Cellular mechanisms in higher plants governing tolerance to cadmium toxicity. Crit. Rev. Plant Sci. 33, 374-391. 
Egendorf, S.P., Groffman, P., Moore, G., Cheng, Z., 2020. The limits of lead (Pb) phytoextraction and possibilities of phytostabilization in contaminated soil: a critical review. Int. J. Phytorem. 22, 916-930.

Estefan, G., Sommer, R., Ryan, J., 2013. Methods of soil, plant and water analysis, 3rd ed. ICARDA, Beirut pp 65-108

Fang, L., Ju, W., Yang, C., Jin, X., Liu, D., Li, M., Yu, J., Zhao, W., Zhang, C., 2020. Exogenous application of signaling molecules to enhance the resistance of legume-rhizobium symbiosis in $\mathrm{Pb} / \mathrm{Cd}$-contaminated soils. Environ. Pollut 265, 114744.

Gao, Z., 2018. Evaluation of heavy metal pollution and its ecological risk in one river reach of a gold mine in Inner Mongolia, Northern China. Int. Biodeterior. Biodegrad. 128, 94-99.

Gemeda, F.T., Guta, D.D., Wakjira, F.S., Gebresenbet, G., 2021. Occurrence of heavy metal in water, soil, and plants in fields irrigated with industrial wastewater in Sabata town, Ethiopia. Environ. Sci. Pollut. Res. 28, 12382-12396.

Haider, F.U., Liqun, C., Coulter, J.A., Cheema, S.A., Wu, J., Zhang, R., Ma, W., Farooq, M., 2021. Cadmium toxicity in plants: Impacts and remediation strategies. Ecotoxicol. Environ. Saf. 211, 111887.

Hasnaoui, S.E., Fahr, M., Keller, C., Levard, C., Angeletti, B., Chaurand, P., Triqui, Z., Guedira, A., Rhazi, L., Colin, F., Smouni, A., 2020. Screening of native plants growing on a Pb/Zn mining area in eastern Morocco: Perspectives for phytoremediation. Plants 9,11, 1458.

Hu, Y., Gao, Z., Huang, Y., Chen, S., Yang, X., Su, J., Zhao, C., Nan, Z., 2019. Impact of poplar-based phytomanagement on metal bioavailability in low-phosphorus calcareous soil with multi-metal contamination. Sci. Total Environ. 686, 848-855.

Hu, Y., Yu, Z., Fang, X., Zhang, W., Liu, J., Zhao, F., 2020. Influence of Mining and Vegetation Restoration on Soil Properties in the Eastern Margin of the Qinghai-Tibet Plateau. Int. J. Environ. Res. Public Health $17,4288$.

Hu, Y.L., Mgelwa, A.S., Singh, A.N., Zeng, D.H., 2018. Differential responses of the soil nutrient status, biomass production, and nutrient uptake for three plant species to organic amendments of placer gold mine-tailing soils. Land Degrad. Dev. 29, 2836-2845.

Jiang, B., Xing, Y., Zhang, B., Cai, R., Zhang, D., Sun, G., 2018. Effective phytoremediation of low-level heavy metals by native macrophytes in a vanadium mining area, China. Environ. Sci. Pollut. Res. 25, 31272-31282.

Ju, W., Liu, L., Jin, X., Duan, C., Cui, Y., Wang, J., Ma, D., Zhao, W., Wang, Y.Q., Fang, L., 2020. Co-inoculation effect of plant-growth-promoting rhizobacteria and rhizobium on EDDS assisted phytoremediation of $\mathrm{Cu}$ contaminated soils. Chemosphere 254, 126724. 
Kanwar, V.S., Sharma, A., Srivastav, A.L., Rani, L., 2020. Phytoremediation of toxic metals present in soil and water environment: a critical review. Environ. Sci. Pollut. Res. 27, 44835-44860.

Keshavarzi, A., Kumar, V., 2019. Ecological risk assessment and source apportionment of heavy metal contamination in agricultural soils of Northeastern Iran. Int. J. Environ. Health Res. 29, 544-560.

Lam, E.J., Cánovas, M., Gálvez, M.E., Montofré, Í.L., Keith, B.F., Faz, Á., 2017. Evaluation of the phytoremediation potential of native plants growing on a copper mine tailing in northern Chile. J. Geochem. Explor. 182, 210-217.

Liu, C.W., Chen, Y.Y., Kao, Y.H., Maji, S.K., 2014. Bioaccumulation and translocation of arsenic in the ecosystem of the Guandu Wetland, Taiwan. Wetlands 34, 129-140.

Lotfolahi, B., Hoodaji, M., Afyuni, M., 2011. Cadmium phytoextraction efficiency by Sorghum bicolor and Helianthus annuus. J. Res. Sci. Tech. 8, 15-20.

Miranda, L.S., Ayoko, G.A., Egodawatta, P., Hu, W.P., Ghidan, O., Goonetilleke, A., 2021. Physico-chemical properties of sediments governing the bioavailability of heavy metals in urban waterways. Sci. Total Environ. 763, 142984.

Nejad, Z.D., Rezania, S., Jung, M.C., Al-Ghamdi, A.A., Mustafa, A.E.Z.M., Elshikh, M.S., 2021. Effects of fine fractions of soil organic, semi-organic, and inorganic amendments on the mitigation of heavy metal (loids) leaching and bioavailability in a post-mining area. Chemosphere 271, 129538.

Pinto, E., Aguiar, A.A., Ferreira, I.M., 2014. Influence of soil chemistry and plant physiology in the phytoremediation of $\mathrm{Cu}, \mathrm{Mn}$, and Zn. Crit. Rev. Plant Sci. 33, 351-373.

Rizwan, M., Ali, S., ur Rehman, M. Z., Maqbool, A., 2019. A critical review on the effects of zinc at toxic levels of cadmium in plants. Environ. Sci. Pollut. Res. 26, 6279-6289.

Shackira, A.M., Puthur, J.T., 2017. Enhanced phytostabilization of cadmium by a halophyte-Acanthus ilicifolius L. Int. J. Phytorem., 19, 319-326.

Sharifi, Z., Sinegani, A.A.S., Shariati, S., 2012. Potential of indigenous plant species for the phytoremediation of arsenic contaminated land in Kurdistan, Iran. Soil. Sediment. Contaminat. 21, 557573.

Sui, J.X., Li, J.W., Jin, X.Y., Vasconcelos, P., Zhu, R., 2018. 40Ar/39Ar and U-Pb constraints on the age of the Zaozigou gold deposit, Xiahe-Hezuo district, West Qinling orogen, China: Relation to early Triassic reduced intrusions emplaced during slab rollback. Ore Geol. Rev. 101, 885-899.

Sun, Y., Li, H., Guo, G., Semple, K.T., Jones, K.C., 2019. Soil contamination in China: Current priorities, defining background levels and standards for heavy metals. J. Environ. Manage. 251, 109512. 
Tabelin, C.B., Silwamba, M., Paglinawan, F.C., Mondejar, A.J.S., Duc, H.G., Resabal, V.J., Opiso, E.M., Igarashi, T., Tomiyama, S., Ito, M., Hiroyoshi, N., Villacorte-Tabelin, M., 2020. Solid-phase partitioning and release-retention mechanisms of copper, lead, zinc and arsenic in soils impacted by artisanal and smallscale gold mining, ASGM activities. Chemosphere 260, 127574.

Wang, L., Hou, D., Shen, Z., Zhu, J., Jia, X., Ok, Y.S., Tack, F., Rinklebe, J., 2020. Field trials of phytomining and phytoremediation: A critical review of influencing factors and effects of additives. Crit. Rev. Env. Sci. Technol. 50, 2724-2774.

Wang, X., Fang, L., Beiyuan, J., Cui, Y., Peng, Q., Zhu, S., Wang, M., Zhang, X., 2021. Improvement of alfalfa resistance against $\mathrm{Cd}$ stress through rhizobia and arbuscular mycorrhiza fungi co-inoculation in $\mathrm{Cd}$ contaminated soil. Environ. Pollut. 277, 116758.

Wei, C.Y., Chen, T.B., 2006. Arsenic accumulation by two brake ferns growing on an arsenic mine and their potential in phytoremediation. Chemosphere 63, 1048-1053.

Xu, Z., Chang, Y., Li, L., Luo, Q., Xu, Z., Li, X., Song, X., Wang, Y., Cao, Y.E., 2018. Climatic and topographic variables control soil nitrogen, phosphorus, and nitrogen: Phosphorus ratios in a Picea schrenkiana forest of the Tianshan Mountains. PloS one 13,11, e0204130.

Yang, W., Wang, Y., Liu, D., Hussain, B., Ding, Z., Zhao, F., Yang, X., 2020. Interactions between cadmium and zinc in uptake, accumulation and bioavailability for Salix integra with respect to phytoremediation. Int. J. Phytorem. 22,6, 628-637.

Yu, X., Shen, T., Kang, X., Cui, Y., Chen, Q., Shoaib, M., Liu, H., Zhang, F., Hussain, S., Xiang, Q., Zhao, K., Gu, Y., Ma, M., Li, S., Zou, L., Liang, Y., 2021. Long-term phytoremediation using the symbiotic Pongamia pinnata reshaped soil micro-ecological environment. Sci. Total Environ. 145112.

Yuan, W., Li-Fei, Y., Zhang, J.C., Yuan-Chun, Y., Deangelis, D.L., 2011. Relationship between vegetation restoration and soil microbial characteristics in degraded karst regions: a case study. Pedosphere, 21, $132-138$.

Zhang, J., Yang, N., Geng, Y., Zhou, J., Lei, J., 2019. Effects of the combined pollution of cadmium, lead and zinc on the phytoextraction efficiency of ryegrass (Lolium perenne L.). RSC adv. 9, 20603-20611.

Zhou, X.Y., Wang, X.R., 2019. Impact of industrial activities on heavy metal contamination in soils in three major urban agglomerations of China. J. Cleaner Prod. 230, 1-10.

\section{Tables}

Table 1 Basic characteristics in the rhizosphere soils 


\begin{tabular}{|llllll|}
\hline Plant species & $\mathrm{pH}$ & $\mathrm{EC}$ & $\mathrm{SOM}$ & Total P & Total N \\
\hline P.pratensis & $8.08 \pm 0.10$ & $85.47 \pm 26.22$ & $69.65 \pm 14.57$ & $0.47 \pm 0.11$ & $2.60 \pm 0.11$ \\
\hline E.nutans & $7.67 \pm 0.12$ & $84.07 \pm 9.11$ & $64.38 \pm 29.82$ & $0.39 \pm 0.06$ & $2.20 \pm 0.61$ \\
\hline P.saundersiana & $7.50 \pm 0.15$ & $83.23 \pm 8.35$ & $54.15 \pm 15.25$ & $0.33 \pm 0.06$ & $2.01 \pm 0.51$ \\
\hline G.pylzowianum & $7.38 \pm 0.25$ & $95.90 \pm 7.89$ & $43.16 \pm 12.49$ & $0.38 \pm 0.10$ & $1.91 \pm 0.33$ \\
\hline C.lipskyi & $7.64 \pm 0.35$ & $109.17 \pm 8.96$ & $57.08 \pm 20.58$ & $0.40 \pm 0.22$ & $2.01 \pm 0.51$ \\
\hline L.sagitta & $7.63 \pm 0.10$ & $102.43 \pm 32.76$ & $65.57 \pm 10.62$ & $0.47 \pm 0.09$ & $2.38 \pm 0.60$ \\
\hline P.fruticosa & $7.54 \pm 0.11$ & $89.57 \pm 15.76$ & $37.28 \pm 5.53$ & $0.39 \pm 0.09$ & $2.04 \pm 0.48$ \\
\hline A.frigida & $7.36 \pm 0.16$ & $81.40 \pm 3.36$ & $72.22 \pm 36.69$ & $0.33 \pm 0.08$ & $2.56 \pm 0.50$ \\
\hline R.nepalensis & $7.29 \pm 0.10$ & $73.43 \pm 23.02$ & $57.99 \pm 14.10$ & $0.48 \pm 0.08$ & $2.49 \pm 0.32$ \\
\hline T. mongolicum & $7.81 \pm 0.08$ & $118.07 \pm 18.13$ & $43.18 \pm 12.40$ & $0.30 \pm 0.10$ & $2.02 \pm 0.45$ \\
\hline G.paludosa & $7.70 \pm 0.18$ & $90.77 \pm 13.96$ & $93.56 \pm 82.38$ & $0.41 \pm 0.08$ & $2.58 \pm 0.73$ \\
\hline S.tetraptera & $7.75 \pm 0.28$ & $115.37 \pm 7.98$ & $39.62 \pm 10.26$ & $0.43 \pm 0.02$ & $2.02 \pm 0.51$ \\
\hline
\end{tabular}

Table 2 PETs concentrations (mean \pm SD) of the rhizosphere soils $\left(\mathrm{mg} \mathrm{kg}^{-1}\right)$ 


\begin{tabular}{|lllll|}
\hline Plant species & As & $\mathrm{Cd}$ & $\mathrm{Zn}$ & $\mathrm{Pb}$ \\
\hline P.pratensis & $36.53 \pm 18.79 \mathrm{c}$ & $0.16 \pm 0.01 \mathrm{~d}$ & $82.66 \pm 7.49$ & $32.90 \pm 5.68$ \\
\hline E.nutans & $22.61 \pm 6.27 \mathrm{c}$ & $0.16 \pm 0.035 \mathrm{~d}$ & $84.74 \pm 2.37$ & $35.58 \pm 7.47$ \\
\hline P.saundersiana & $27.67 \pm 10.23 \mathrm{c}$ & $0.15 \pm 0.021 \mathrm{~d}$ & $82.88 \pm 0.38$ & $40.53 \pm 2.76$ \\
\hline G.pylzowianum & $28.00 \pm 7.19 \mathrm{c}$ & $0.34 \pm 0.086 \mathrm{c}$ & $84.53 \pm 6.64$ & $32.95 \pm 6.51$ \\
\hline C.lipskyi & $27.31 \pm 6.32 \mathrm{c}$ & $0.17 \pm 0.012 \mathrm{~d}$ & $82.33 \pm 5.02$ & $27.23 \pm 2.54$ \\
\hline L.sagitta & $27.92 \pm 1.35 \mathrm{c}$ & $0.15 \pm 0.021 \mathrm{~d}$ & $79.94 \pm 3.05$ & $37.51 \pm 6.09$ \\
\hline P.fruticosa & $22.43 \pm 1.21 \mathrm{c}$ & $0.42 \pm 0.105 \mathrm{c}$ & $86.51 \pm 4.51$ & $28.22 \pm 1.81$ \\
\hline A.frigida & $26.42 \pm 3.78 \mathrm{c}$ & $0.16 \pm 0.015 \mathrm{~d}$ & $83.89 \pm 2.84$ & $37.32 \pm 4.69$ \\
\hline R.nepalensis & $106.74 \pm 44.75 \mathrm{~b}$ & $0.16 \pm 0.02 \mathrm{~d}$ & $88.15 \pm 2.61$ & $31.10 \pm 5.39$ \\
\hline T.mongolicum & $26.55 \pm 2.22 \mathrm{c}$ & $0.16 \pm 0.027 \mathrm{~d}$ & $88.78 \pm 2.30$ & $32.04 \pm 3.24$ \\
\hline G.paludosa & $23.27 \pm 4.19 \mathrm{c}$ & $1.01 \pm 0.197 \mathrm{a}$ & $83.50 \pm 3.63$ & $40.01 \pm 4.06$ \\
\hline S.tetraptera & $144.22 \pm 36.91 \mathrm{a}$ & $0.71 \pm 0.099 \mathrm{~b}$ & $85.85 \pm 8.63$ & $35.26 \pm 4.64$ \\
\hline Background level & 11.2 & 0.1 & 74.2 & 26.0 \\
\hline Limit & 25.0 & 0.5 & 250.0 & 80.0 \\
\hline
\end{tabular}

Figures 


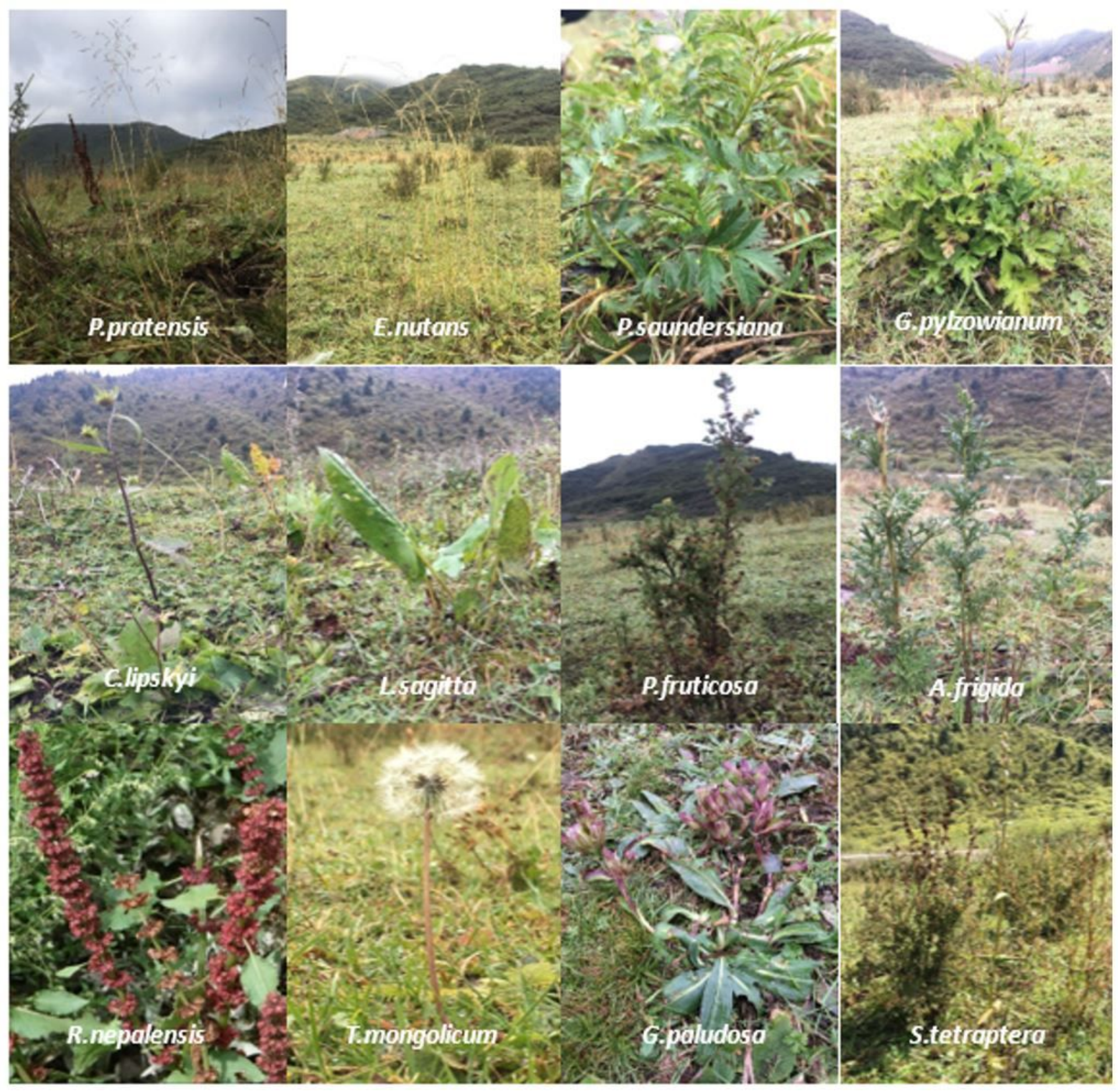

Figure 1

Native plant species in the mining area 


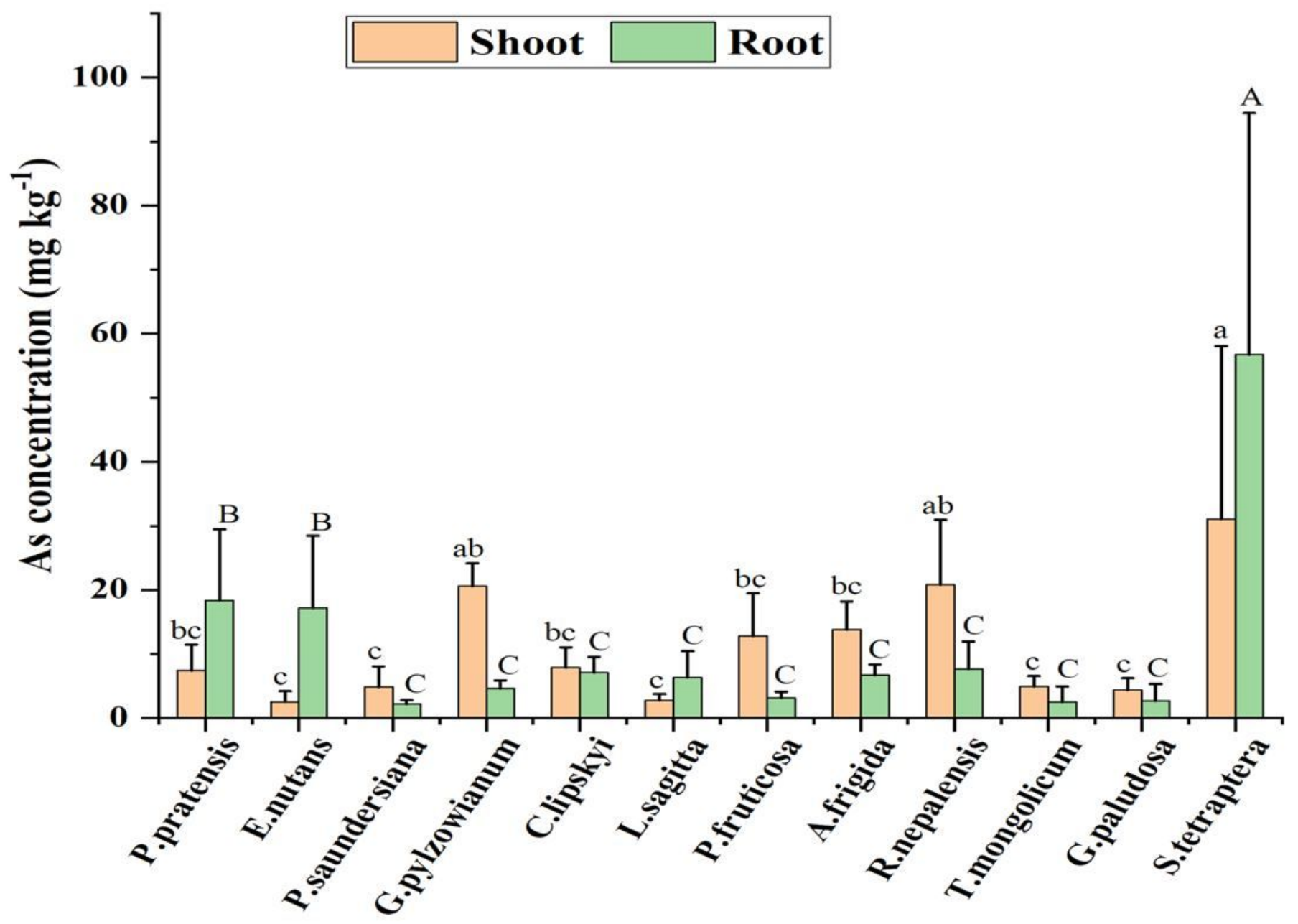

Figure 2

As concentration in 12 native plant species from the mining area. Note: The different lower letters and upper letters indicate groups that are marked differences at the $p<0.05$ in the shoots and roots, respectively. 


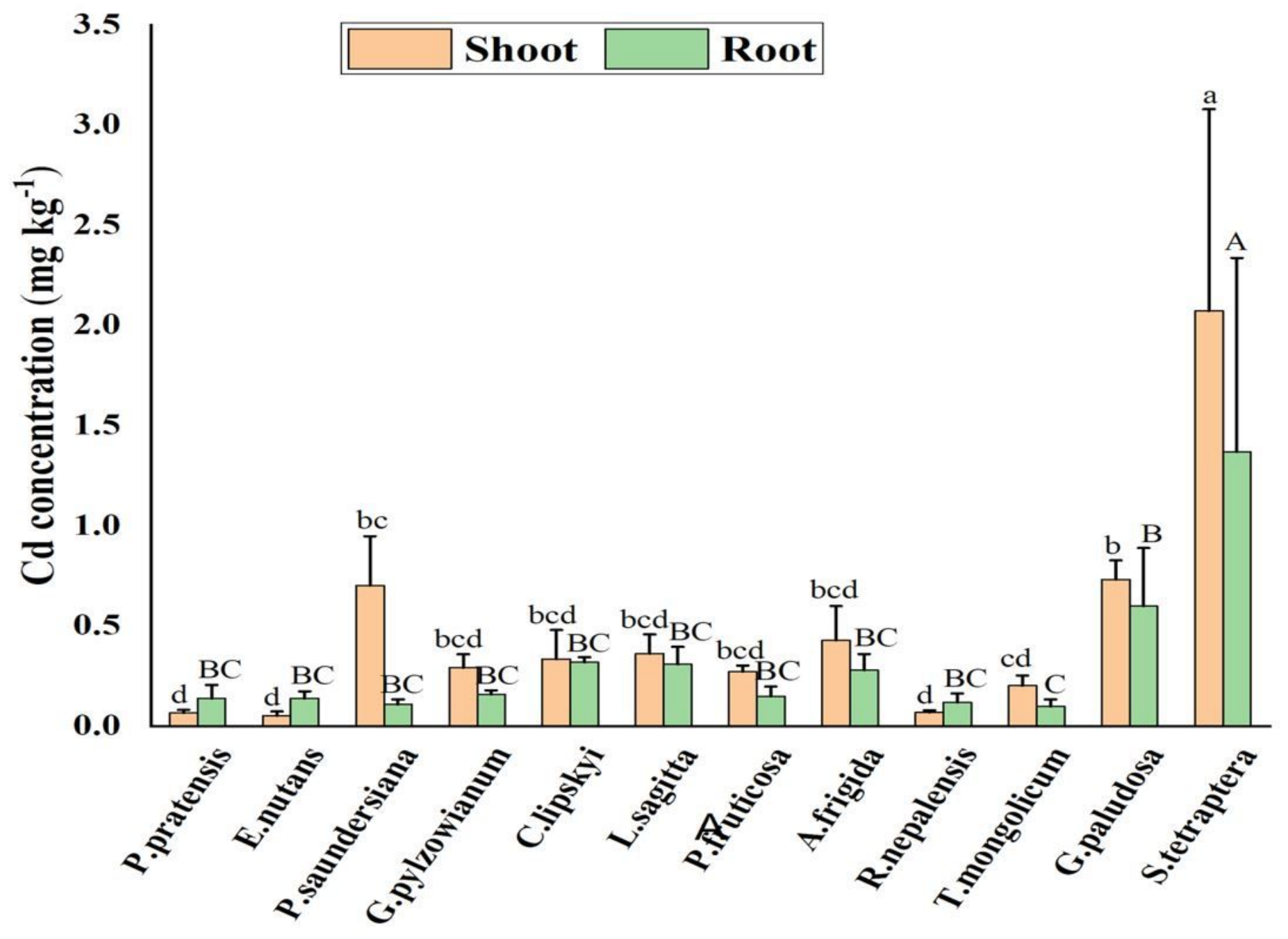

Figure 3

Cd concentration in 12 native plant species from the mining area. Note: The different lower letters and upper letters indicate groups that are marked differences at the $p<0.05$ in the shoots and roots, respectively. 


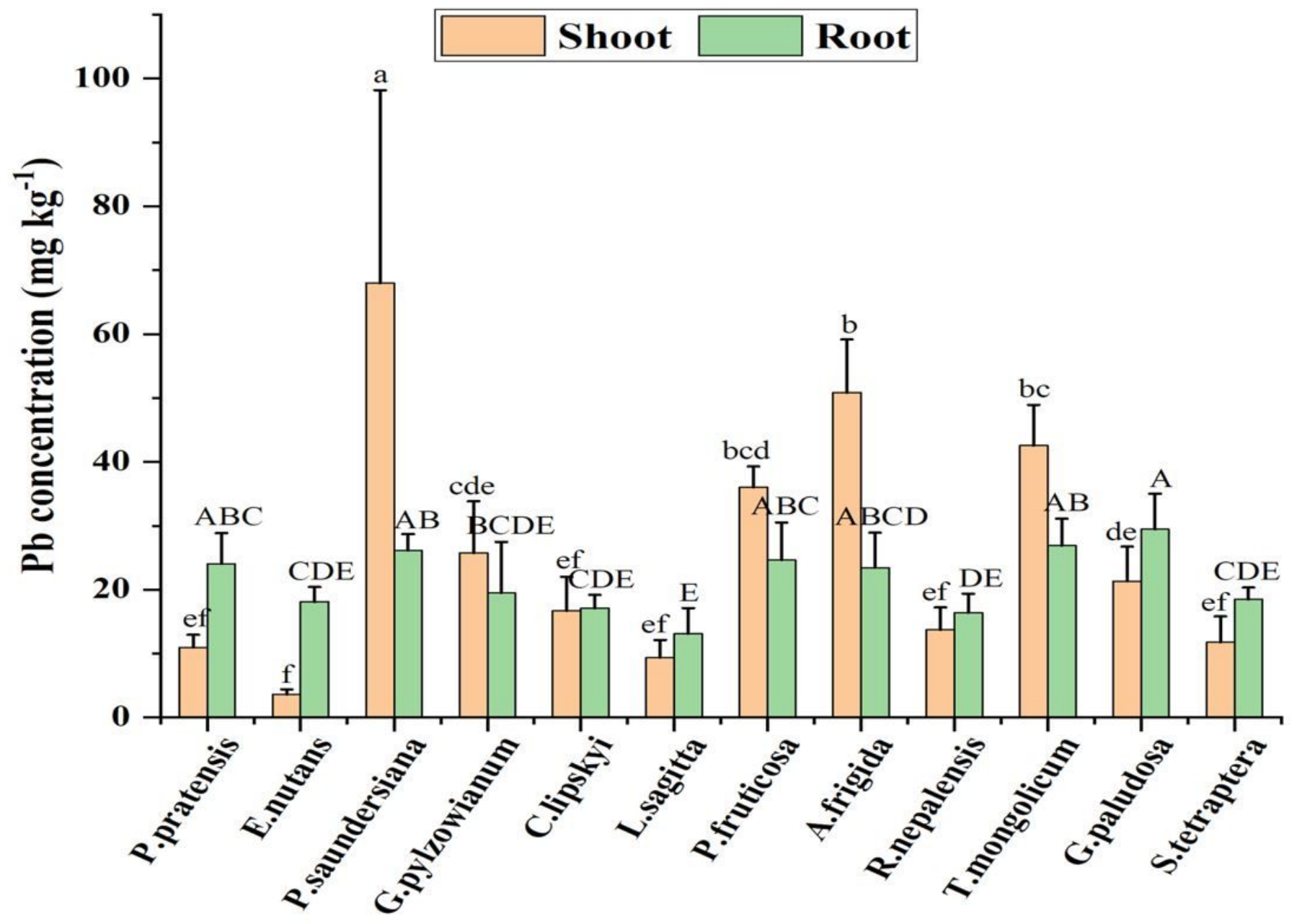

Figure 4

$\mathrm{Pb}$ concentration in 12 native plant species from the mining area. Note: The different lower letters and upper letters indicate groups that are marked differences at the $p<0.05$ in the shoots and roots, respectively. 


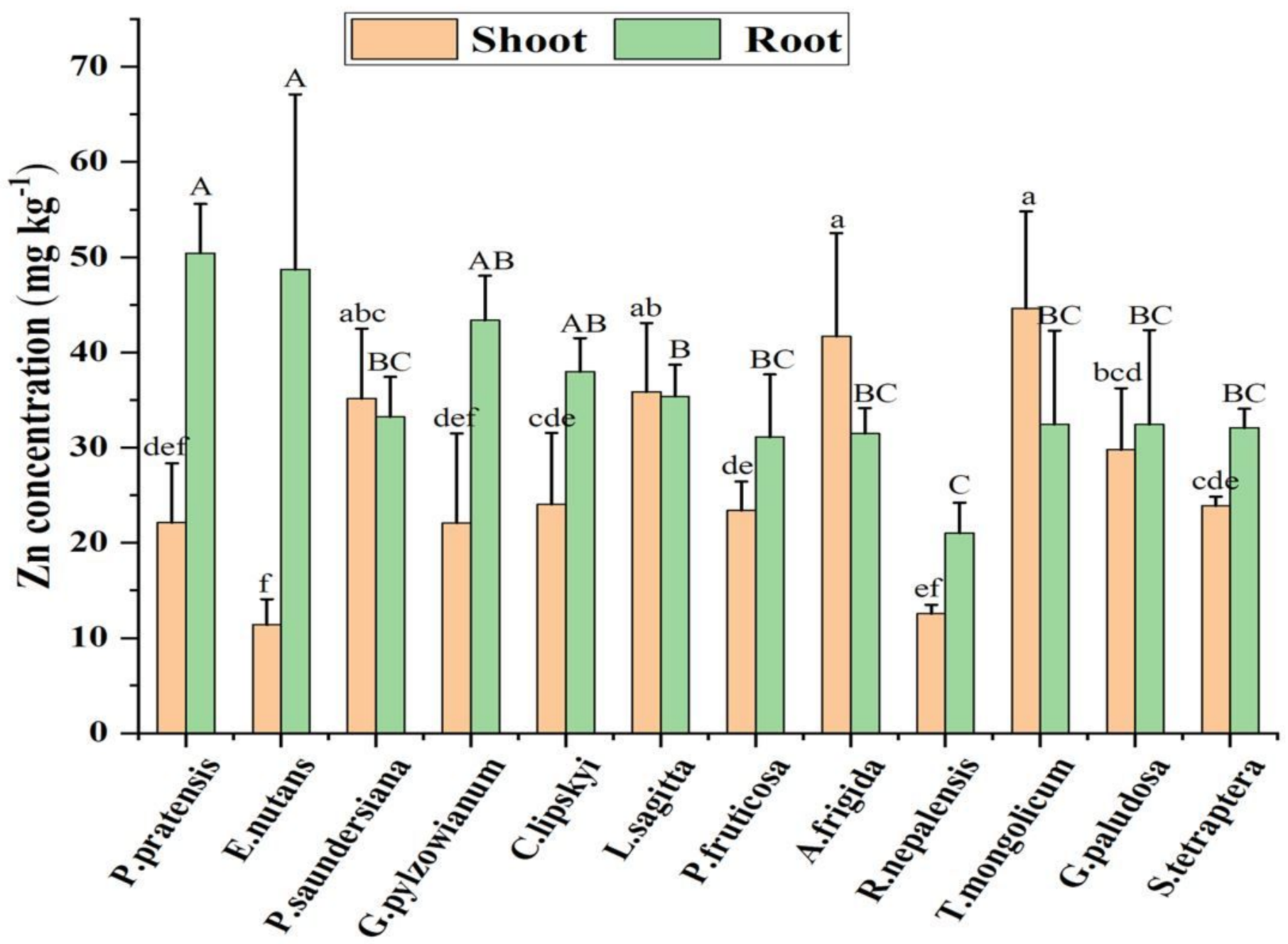

Figure 5

$\mathrm{Zn}$ concentration in 12 native plant species from the mining area. Note: The different lower letters and upper letters indicate groups that are marked differences at the $p<0.05$ in the shoots and roots, respectively. 


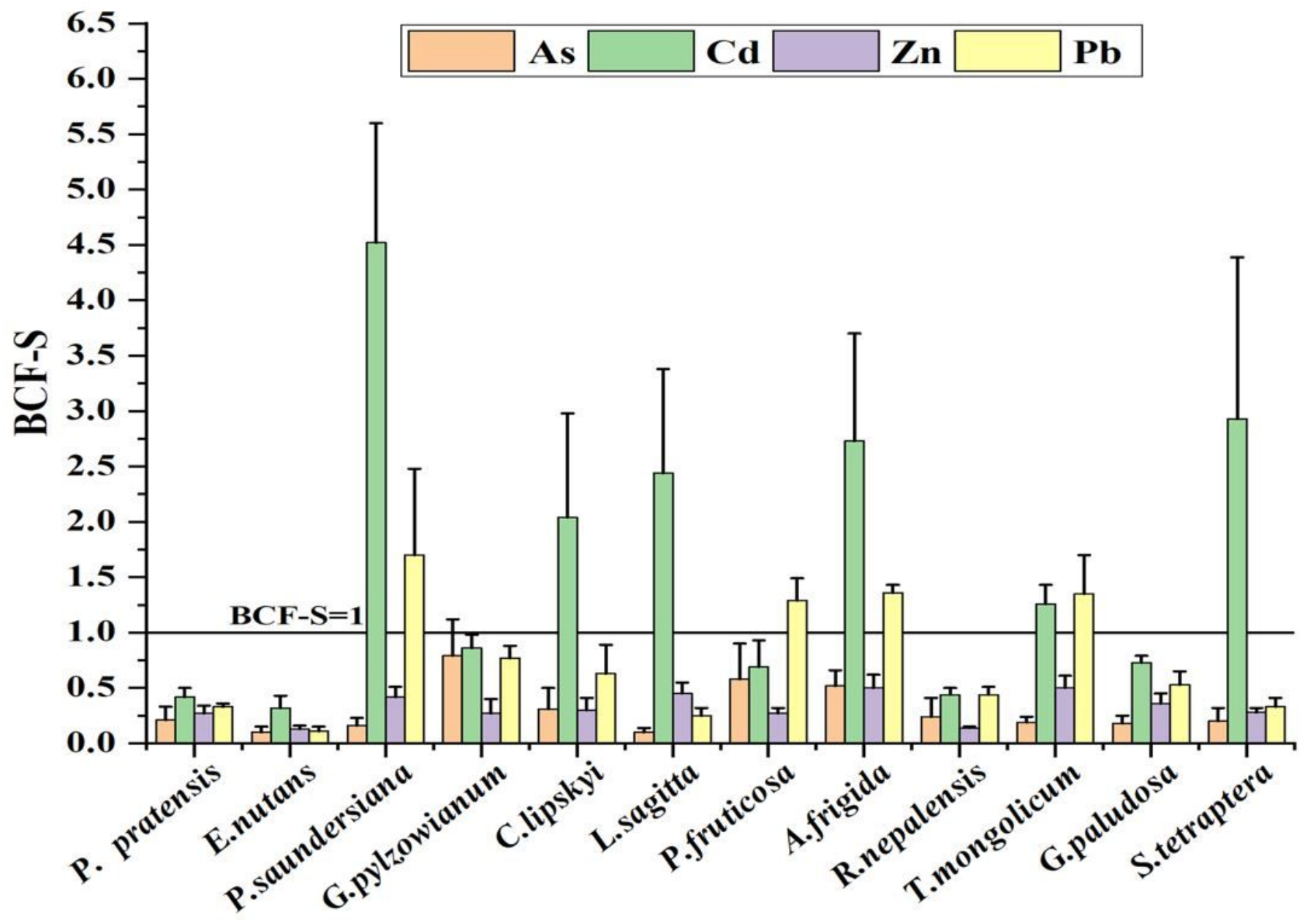

Figure 6

The BCF-S (mean \pm SD) of 12 native plant species collected from the mining soils. 


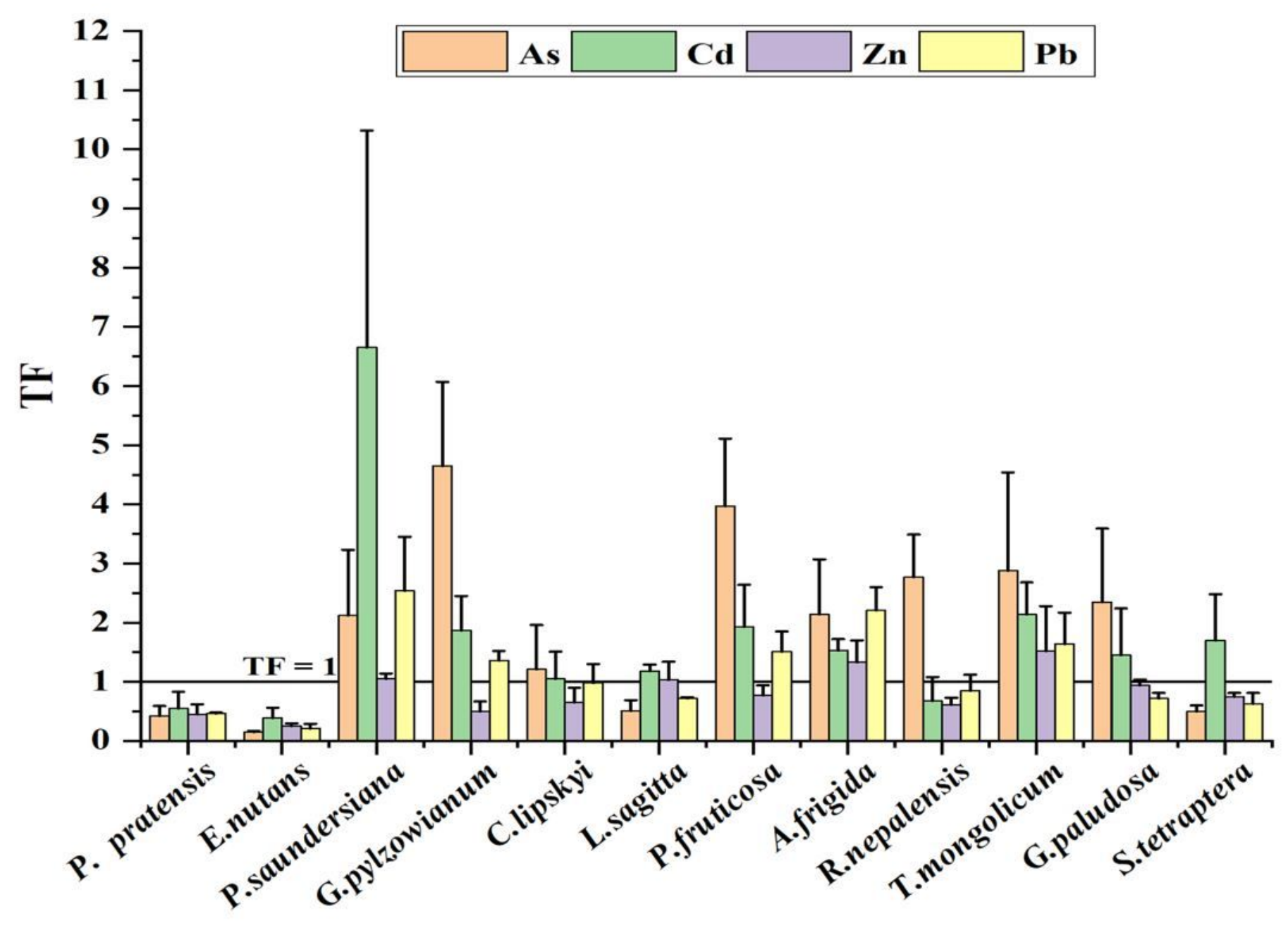

Figure 7

The TF (mean \pm SD) of 12 native plant species collected from the mining soils.

\section{Supplementary Files}

This is a list of supplementary files associated with this preprint. Click to download.

- SupplementaryMaterial.docx 